\title{
National Poverty Eradication Programme in Nigeria (NAPEP): A Case Study of Capacity Acquisition Programme (CAP) in Gombe State 2003 - 2010
}

\author{
Babayo Sule \\ Department of Political Science, Faculty of Humanities Management and Social \\ Sciences, Federal University Kashere Gombe, Gombe State \\ Umar Adamu \\ 2Department of Public Administration, Faculty of Arts and Social Sciences, Gombe \\ State University \\ E-mail: umaradamutj@gmail.com \\ Muhammad Aminu Yahaya \\ 3Department of Public Administration, Faculty of Arts and Social Sciences, Gombe \\ State University \\ E-mail: abusafiyyah9032@gmail.com
}

Received: April 11, 2019 Accepted: June 9, 2019 Online published: June 13, 2019

doi:10.5296/jpag.v9i2.14650 URL: https://doi.org/10.5296/jpag.v9i2.14650

\begin{abstract}
Poverty is one of the major socio-economic problems in Nigeria which draws the concern of policy-makers in Nigeria of recently. In response to the scourge of poverty in Nigeria, the civilian government of Obasanjo introduced Poverty Alleviation Programme (PAP) in 2000 but later, PAP was halted and replaced with National Poverty Eradication Programme (NAPEP) in 2001. NAPEP has a multi-various approach to poverty eradication including Capacity Acquisition Programme (CAP) which is an emphasis on skills acquisition and training for self-reliance. The major problem is the way poverty is increasing in alarming rate despite various efforts by government to eradicate it in the period of this study. This study examined CAP in Gombe state and its impact on poverty eradication effort. The methodology adopted for this research is the use of primary source where interview was conducted with
\end{abstract}


one local government chosen from each of the three zones of the state. Secondary source was also used where literature was reviewed theoretical framework was formed to support the arguments presented. The data obtained were presented and analysed together with the hitherto existing statistics on this area. The research discovered that CAP as a component of NAPEP programme achieved little success in poverty eradication as a result of government's unseriousness, corruption and negligence. Thus, the policy is not ideal for poverty eradication approach. The best means of poverty eradication is employment generation through provision of small scale and large-scale industries, eradication of corruption and genuine political will from the part of policy makers.

Keywords: capacity acquisition, eradication, human development index, human poverty index, poverty

\section{Introduction}

Poverty in affluence is one of the major challenges of the globe and Nigeria in particular in contemporary times (Kpakol, 2007:445). According to National Bureau of Statistics in 2015, it is estimated that about $70 \%$ are living below poverty line which signifies a serious concern for policy makers and all stakeholders in the country (National Bureau of Statistics, 2015). The above figure signifies an increase in the incidence of poverty in Nigeria without any improvement since by 2006 , the percentage of those living in poverty was $64.4 \%, 70.6 \%$ in 2007 and 70\% in 2010 and 2012 respectively (United Nations Development Programme 2012 and National Bureau of Statistics 2012).

Nigeria is one of the countries that are noted for the prevalence of absolute poverty in all its characteristic features. Poverty in the country is massive, pervasive and chronic, engulfing a large proportion of the society. Concern about poverty in Nigeria is great (Odusola, 1997:121). Poverty is more endemic in Northeastern Nigeria where the states are considered as the poorest in the country consisting of Adamawa, Bauchi, Borno, Gombe, Taraba and Yobe. Gombe State is one of the poorest states in the country emerging as the third poorest state in 2013 according to NBS statistics. This study critically examined the policy of Capacity Acquisition programme (CAP) in Gombe State from 2003-2015. CAP is one of the six multi-sectoral approaches of National Poverty Eradication programme (NAPEP) introduced in 2001. NAPEP is a continuation of Poverty Alleviation programme which was established in 2000 but later halted by Obasanjo civilian regime and replaced with NAPEP in 2001.

This work titled "National Poverty Eradication Programme in Nigeria (NAPEP): a Case Study of Capacity Acquisition Programme (CAP) in Gombe State is an important area of study in Nigerian context because poverty is one of the major social and economic concern for policy-making in the country owing to its high incidence which means works like this research is of greater need in the country to ameliorate the scorch of social and economic sufferings. The motive of this study is to examine the policy of Capacity Acquisition Programme (CAP) as a part of the National Poverty Alleviation Programme (NAPEP) in one of the poorest states in the country to analyse its success and challenges and whether to continue with the programme or to look for an alternative. In addition, the work investigated 
the impact of capacity Acquisition Programme (CAP) in Gombe State especially on the target beneficiaries and the wider community at large the problems that are associated with Capacity Acquisition Programme (CAP) as a means of poverty eradication in Gombe State. The contribution of the study is practical implication for policy-makers in terms of using the findings for policy review and continuity or searching for alternative. The study has a general contribution to knowledge in which a knowledge gap was identified in the subject matter of study and filled because there was no such study in Gombe State and even in Nigeria at large which analyse CAP as part of NAPEP policy and evaluate it for its success or challenges.

\section{Literature Review}

\subsection{Poverty in Nigeria}

According to Dependency scholars like Rodney (1972), Onimode (1983), Offiong (1980), the poverty of Africa and Nigeria in particular is rooted in the unequal relationship developed between the continent and country and the industrialized capitalist countries via the slave trade, the legitimate trade, colonialism and neo-colonialism. The World Bank however associated poverty in Nigeria with mainly macroeconomic problems including fall in oil revenues, excessive borrowing, drift and decline in wages (Fwatshak, 2001:180 and Orji, 2008:13).

In another analysis with much emphasis on neo-colonial Nigeria, poverty is summed up the as the negative impact of colonialism which merged different heterogeneous societies that after independence, national resources are allocated, based on tribal cleavages creating wars, destruction of lives and properties, causing poor means of life (Magaji,2005:39). Culture impoverishment via globalization is seen as a major cause of poverty (Nwagbara, 2001:201).

Ijaiya (2007:47) reiterates that the factors that cause poverty include: (i) structural causes that are more permanent and depend on a host of factors such as limited resources, lack of skill, location disadvantage and other factors that are inherent in the social and political set up and (ii) the transitional causes that are mainly due to structural adjustment reforms and changes in domestic economic policies that may result in price changes, increase unemployment; e.t.c. Natural calamities such as wars, environmental degradation e.t.c, also include transitory poverty.

Aliyu (2008) also attributes the poverty in Nigeria to the following factors:

i. Poor macro-economic and monetary policies resulting in low economic growth rate and continues slide in the value of Naira which depreciated from N 1.0 to 140.00 to $\$ 1.0$ between June 1986 and March 2000 in the parallel market,

ii. Dwindling performance of the manufacturing sector which has the capacity to employ about 20 million people but currently employs only about 1.5 million by all the 2,750 registered members of the Manufacturers Association of Nigeria (MAN).

iii. Increasing foreign debt overhang of almost $\$ 30$ billion, requiring $\$ 3.5$ billion annually for resettlement from an economy earning just about $\$ 10.0$ to $\$ 15.0$ billion per annum. 
iv. Poor management of the nation's resources coupled with large scale fraud and corruption, most which has been siphoned out of the country in hard currency. This is a country endowed with abundant resources in which between 1970s and now, the nations have earned over $\$ 300$ billion from oil revenues alone. By 1970s, Nigeria was among the fifty richest nations in the World, but by 1999, Nigeria was among the twenty-five poorest nations of the world; and

v. Poor execution of government programmes and projects, especially those projects aimed at the provision of social welfare services such as education, health, and those aimed at the provision of economic infrastructures.

Poverty incidence in Nigeria manifested itself as unevenly distributed in the country. The distribution pattern of poverty in Nigeria shows that by 2002, national poverty incidence had increased to $48.5 \%$ from $34.1 \%$ recorded in 1999 , further analysis from geo-political zones of the country shows distribution as follows; -

Table 1. Poverty Index by Geo-Political Zone in Nigeria

\begin{tabular}{ll}
\hline Geo-Political Zones & Percentage \\
\hline North - East & $55.9 \%$ \\
North - West & $55.0 \%$ \\
North - Central & $49.8 \%$ \\
South - West & $48.4 \%$ \\
South - South & $39.8 \%$ \\
South - East & $38.8 \%$ \\
\hline
\end{tabular}

Source: Year Book 2004 Human Poverty

Available data also indicate that the rate of poverty in Nigeria rose from $28 \%$ in 1980 to about $70 \%$ in 2003, the nation's per capita income reduced from $\$ 698$ in 1980 to $\$ 290$ in 2003 and the nation's ranking in human development index (HDI) was 158 in 2003 dropping from 129 in 1990 out of 177 countries (2005). However, from 1996 to 2004, poverty level dropped in Nigeria from $65.6 \%$ in 1996 to $54.4 \%$ in 2004 at the national level. This is significant because within this period, there were active poverty eradication programme.

Table 2. National Poverty Level 1980 - 2015

\begin{tabular}{ll}
\hline Year & Poverty level \% \\
\hline 1980 & $27.2 \%$ \\
1985 & $46.3 \%$ \\
1992 & $42.7 \%$ \\
1996 & $65.6 \%$ \\
2004 & $54.4 \%$ \\
2007 & $70.6 \%$ \\
2010 & $70 \%$ \\
2012 & $70 \%$ \\
2013 & $63.4 \%$ \\
2014 & $61.2 \%$ \\
2015 & $62.6 \%$ \\
\hline
\end{tabular}


Source: National Bureau of statistics 2015.

The CBN and NBS socio-economic survey of 2006 and the NBS CWIP of 2006 further confirm the poverty situation in the country across regions and states. It was evident from the study that a substantial proportion of Nigerians still live on less than N 20,000 a year. There is a clear evidence of high dispersion in per capita incomes across the 36 states of the federation as at 2007. High performers included the FCT $(10,208)$, Bayelsa $(\$, 5,388)$, Rivers $(\$ 5,210)$, Akwa Ibom $(\$ 3,813)$, Lagos $(\% 2,554)$ and Delta $(\$ 147)$ while the low performing states were Taraba (\$141), Kogi (\$147), Anambra (\$163), Gombe (\$166), Osun (\$183) and Plateau (\$194). Other states fell between the two groups. The oil producing states continue to dominate the high performing states, while 18 states recorded lower per capita income than the global standard of less than $\$ 1.25$ per day.

Table 3. Indicating the Per Capita Income in the 36 States of Nigeria

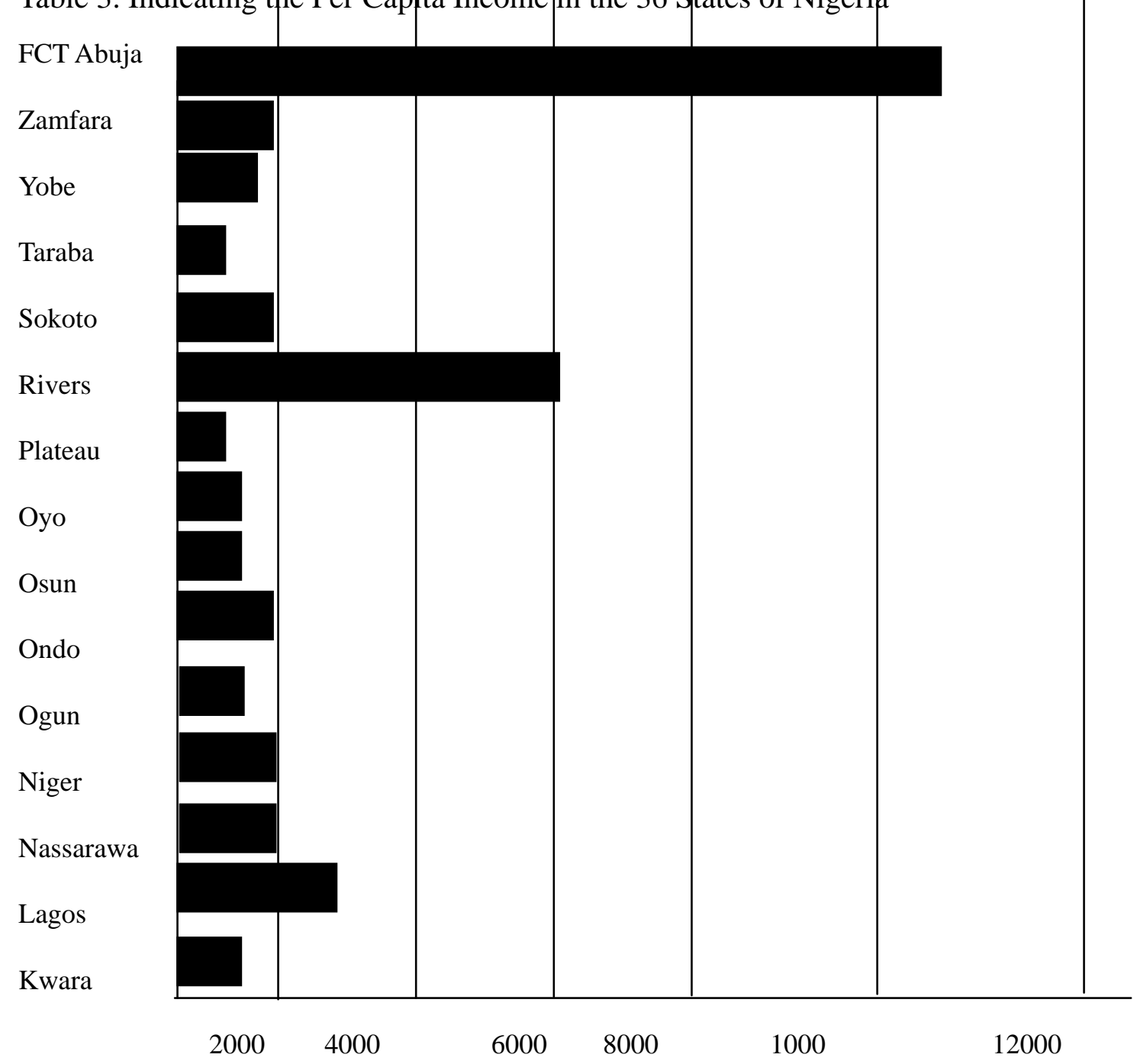


Kebbi

Katsina

Kano

Kaduna

Jigawa

Imo

Gombe

Enugu

Ekiti

Edo

Ebonyi

Delta

Cross river

Borno

Benue

Bayelsa

Bauchi

Anambra

Akwa-Ibom

Adamawa

Abia
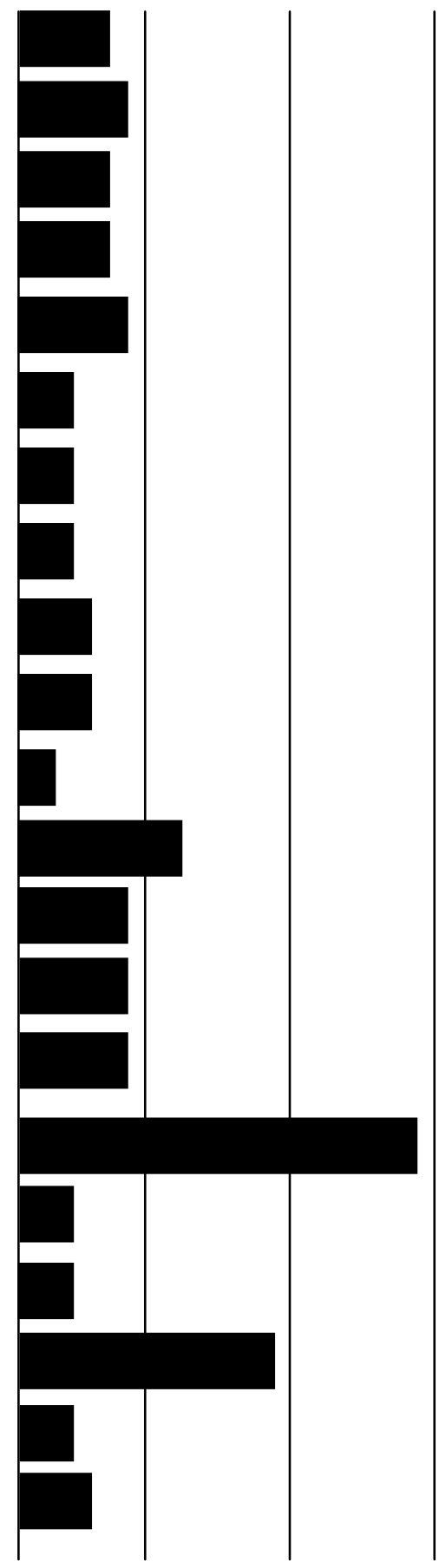

2000

4000

6000

8000

Source: Human Development Index, 2008

Human Development Report in Nigeria 2008 - 2009

\subsection{National Poverty Eradication Programme in Nigeria (NAPEP): A Review}

The poverty alleviation programme introduced in Nigeria was a response to the devastating nature of poverty in the country and the alarming rate with which it is increasing over the years. Despite the plethora of poverty alleviation programmes which past governments had 
initiated and implemented, by 1999 when the Obasanjo Administration came to power, a World Bank report indicated that Nigeria's Human Development Index (HDI) was only 0.416 and that about $70 \%$ of the population was vegetating below the bread line.

These alarming indicators prompted the government to review the existing poverty alleviation Scheme with a view to harmonizing them and improving on them. Three Presidential Panels were set up in this regard. They were the presidential panel on the Rationalization and Harmonization of poverty Alleviation and Agencies headed by Alhaji Ahmed Joda, Presidential Technical Committee on the Review of All Poverty Alleviation Programmes headed by Professor Ango Abdullahi, and Committees on Youth Policy, Concept of the Youth Empowerment Scheme and the Blueprint for Poverty Eradication Programme headed by Professor A.B Aborishade. The findings and recommendations of these Presidential Panels coalesced in the formation of the National Poverty Eradication Programme in 2001(NAPEP, 2010:1).

It is the target of all tiers of government in Nigeria to eradicate absolute poverty among Nigerians through the implementation of coordinated and sustained programmes. The ultimate target of the poverty eradication drive at the three tiers of government is to ensure that by the year 2015, all Nigerians have access to the basic needs of life which include:

- Steady source of real income, food, education, roads;

- Portable water, housing

- Health care, security and

- A conducive environment for productive activities.

The above is targeted at ensuring eradication of absolute poverty among the citizenry. NAPEP is the foremost Federal Government Policy charged with the coordination and monitoring of all poverty eradication efforts at all levels of government, and the private sector has been relentlessly explaining new methods to address poverty in Nigeria. NAPEP has been at the foremost of a paradigm shift which emphasise poverty reduction through partnership (Kpakol, 2007:449-450).

According to Ajegi (2002), the new scheme has been structured to integrate six sectoral schemes. The first is the Youth Empowerment Scheme (YES), which is concerned with providing unemployed youth opportunities in skills acquisition, employment and wealth generation. The second scheme is Capacity Acquisition Programme (CAP). This aims at providing an identified section of the affected population with training in various skills and empowerment for self-reliance. Mandatory Attachment Programme (MAP) is the third scheme, which is an attempt to provide a basis for giving credit and training in trade and commerce.

The fourth is the Rural Infrastructure Development (RIDS). The objective of this scheme is to ensure the provision and development of infrastructure needs in the areas of transport, and energy, water and communication especially in rural areas. This scheme has been broken into four parts, the Rural Transport Programme, the Rural Water Programme and the Rural 
Communication Programme.

The fifth is the Social Welfare Services Scheme (SOWESS), which aims at the provision of basic social services including quality primary and special education, strengthen the economic power of farmers, providing primary health care and so on. The sixth is the Natural Resources Development and Conservation Scheme (NRDCS). The vision of this scheme is to bring about a participatory and sustainable development of agriculture, mineral and water resources.

\section{Framework of Analysis}

\subsection{Vicious Circle of Poverty}

Ragnar Nurkse in a book titled "Problems of Capital Formation in Underdeveloped Countries" theorised poverty in a model called "Vicious circle of poverty". According to Nurkse

\section{"In discussion of the problem of economic development, phrase that crops up frequently is the vicious circle of poverty" (1967: 4).}

Vicious circle of poverty implies a circular constellation of forces tending to act and react upon one another in such a way as to keep a poor country in a state of poverty. Particular instance of such circular constellations are not difficult to imagine, for example, a poor man may not have enough to eat, being underfed his health may be weak and being physically weak, his working capacity is low which means that he is poor, a situation of this sort, relating to a country as whole can be summed up in trite proposition hence: a country is poor because it is poor (Nurkse 1967: 4).

Perhaps the most important circular relationship of this kind is those that afflict the accumulation of capital in economically backward countries. The supply of capital is governed by the ability and willingness to save, the demand for capital is governed by the incentive to invest. A circular relationship exists on both side of the problem of capital in the poverty ridden areas of the world. On the supply side, there is a small capacity to save, resulting from the low level of real income as a reflection of low productivity. On the demand side, the inducement to invest may be low because of the purchasing power of the people which is due to their small real income, which again is due to low productivity.

Jhingan (2007: 31-32) further developed and expanded Nurke's theory of Vicious Circle of Poverty, that the basic vicious circle stems from the fact that in less developed countries, total productivity is low due to deficiency of capital market and low investment on human capital, economic backwardness and underdevelopment. This is illustrated below: 

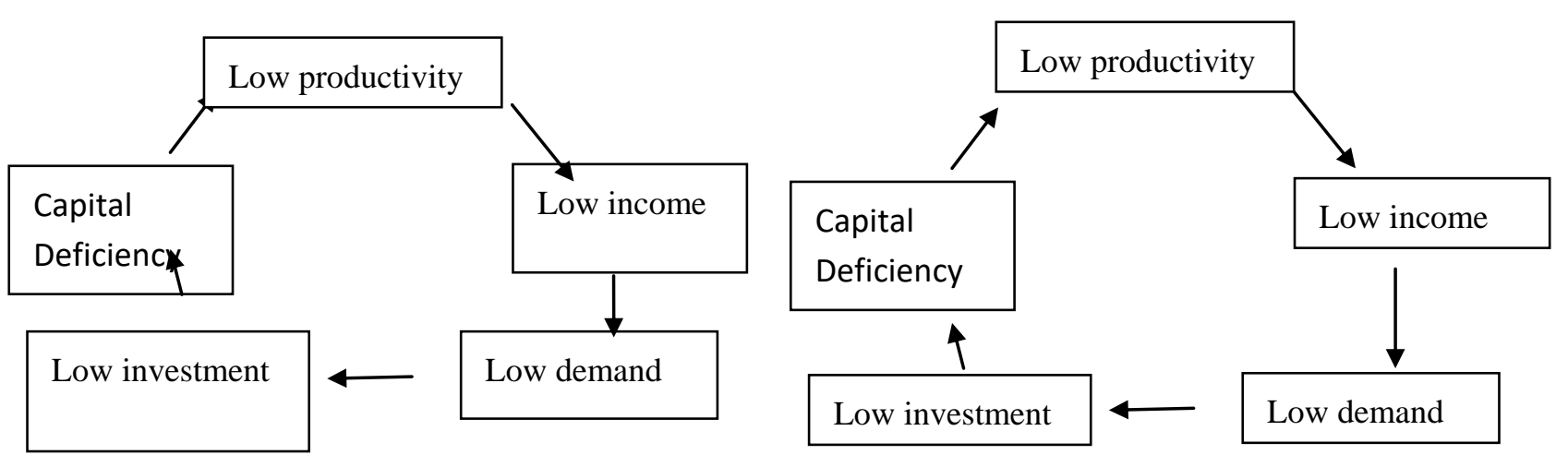

Figure 1. Showing the Circular Flow of Poverty in a Society

Source: Jhingan, 2007

A complement of the vicious circle of poverty envelops underdeveloped human natural resources which is dependent upon the productive capacity of the people in the country. If the people are backward and illiterate, lack in technical skill, knowledge and entrepreneurial activity, the natural resources will tend to remain unutilized, and leading to underutilization or even mis-utilisation. This is explained below.

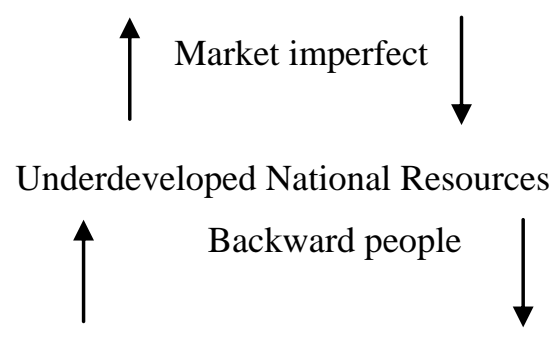

Figure 2. Showing a Complement of the Vicious of Poverty

Source: Jhingan 2007: 31-32

Jhingan (2007:31-32) concludes his proposition of the theory of vicious circle of poverty in the following words; poverty and underdevelopment of the economy are thus synonymous. A country is poor because it is underdeveloped. A country is underdeveloped because it is poor and remains underdeveloped as it has not the necessary resource for promoting the development poverty is a curse, but a greater curse is that it is self-perpetuating.

The vicious circle of poverty proposed the following as a means of eradication of poverty. The first is massive human resource development which leads to increase in savings; secondly, improved higher per capita growth rate. This can be achieved by increasing the level of employment in the country; thirdly, efficient use of both human and material resources. The developing countries are not making the efficient use of their natural resources available to them. At present, the multinational corporations (MNCS) of the advanced countries are exploiting these resources more for their own economic benefit; fourthly improving the quality of human resources in terms of employment generation, good quality 
of labour force, higher literacy level, proper medical care and good supply of balanced diet.

Effective measures have to be taken for sufficient investment in human capital to break up the poverty barrier of the LDCS; fifthly, increasing the stock of capital goods. This can be done by encouraging the wealthy class to make their savings available for investment in productive activities; sixthly, is technological advancement; seventhly, expansion of volume of trade internationally; and finally, political willingness to greatly root out corruption and bribery, it can provide incentive to save and invest, and it can increase agricultural production by introducing effective reforms in the country.

The Vicious Circle of Poverty can clearly explain poverty and poverty eradication policies in Nigeria. Even though some scholars; Myrdal (1974), Ake (1996) and Somasundara (2010) do not absolutely subscribe to the view that poor are likely to remain poor because it is intergenerational. These scholars agreed with Nurkse (1967); Jhingan (2007); and Hill (1985) that, poor are in vicious circle of poverty and are likely to remain so if the government policies are not directed towards genuine National Development.

The vicious circle poverty in Nigeria has the following proposition; a. the individual and nations at large are poor and are rotating within the chain of poverty, b. poor macroeconomic settings such as low income, low investment, low level of demand and supply, technological backwardness, unemployment, inflation etc. which are making poverty persistence in the country c. there is the problem of policy agenda setting which lacks political willingness and sincerity, poverty can be truly eradicated if the leadership of poor countries exhibit good governance and is willing to adopt real development agenda particularly radical investment in human capital.

The theory is capable of explaining the Nigerian situation in reference to NAPEP since it is a programme which gives much emphasis on poverty reduction instead of eradication. A good policy should seek to eradicate poverty because reduction will amount to little changes or the resurgence of that phenomenon which is exactly what the theorists are postulating that the poor are likely to remain in poverty if the policy makers are not serious. Payment of $\$ 3,000$ allowances monthly where the training is not absolutely practiced will not lead to high income, high demand, high supply, high saving and increase productivity. Instead, the process adopted by NAPEP may lead to low attainment of income, supply, demand, and other variable factors which are the ingredient of keeping poor in vicious circle of poverty.

\section{Methodology}

\subsection{Sources of Data}

The method of data collection and analysis for this research is the use of primary and secondary data. The primary source is interview which was conducted through the administration of questionnaire. Also, specified interview was used in the process. The secondary source was the consultation of relevant literature available on the subject matter of this research. This involves textbooks, journals, articles, magazines, newspapers, reports and seminars. 


\subsection{Sampling Method}

The sampling method adopted for this research is simple random sampling. For this study, the sampling size is two hundred and ten (210) selected from three local governments in Gombe State consisting of beneficiaries of Capacity Acquisition Programme (CAP), stakeholders, policy makers and analysts.

\subsection{Sampling Size}

Out of the total number identified as sample, 70 are sampled from Dukku local government which represents Gombe North, 70 from Akko local government representing Gombe Central and 70 from Kaltungo which represents Gombe South. The basis for this choice is because Gombe State is divided into three Senatorial zones with Dukku belonging to Gombe North, Akko Gombe Central and Kaltungo Gombe South. This is to provide a means of comparative analysis. Furthermore, target beneficiaries having given priority will be followed by policy makers in sampling. This is also on the ground that, poverty is more serious in rural areas and besides, Dukku, Akko and Kaltungo are remote areas with higher incidence of poverty mostly affecting women and children. The target beneficiaries were located through National Directorate of Employment (NDE). The policy of Capacity Acquisition Programme (CAP) was jointly undertaken in Gombe State by NAPEP and State Government.

\subsection{Data Analysis}

The raw data obtained was presented in simple tabular statistics and simple percentage and analyzed to come up with research findings. Together with the past findings and various reports, final analysis was made base on the findings of this research.

\section{Findings}

National Poverty Eradication Programme (NAPEP) was established in Gombe state in the year 2002 by the first executive governor under the Secretary to the State Government's office. The plan for NAPEP in Gombe state was outlined to target the unemployed youth, unemployed school leavers, widows and orphans, artisans i.e. radio repairers, local launderers, Achaba transporters and trucks. The plan is to liaise with international, national, state and local donor agencies such as NAPEP (Federal), Millennium Development Goals (MDGS),National Development Programme(NDP) and Department of Foreign International Development(DFID) etc. the plan also sought to employ poverty assistance in all local government coordinators in data collection, loan disbursement and recovery (NAPEP Gombe State, 2007:1).

Gombe State poverty policy succeeded from 2002-2007 in empowering different sectors of the population in the state through its Capacity Acquisition Programme (CAP). Even though the success recorded is minimal compared to what is targeted. NAPEP in Gombe State fail to achieve its target goals appropriately because of the following constraints:

- $\quad$ Lack of support by stakeholders.

- Soft loan beneficiaries do not utilize the loan as expected as a result it seems a "bad debt". 
- Unseriousness from the part of the government.

- Corruption.

- Mismanagement.

- $\quad$ The target beneficiaries are sidelined.

- $\quad$ Shortage of funds.

The CAP is designed to enable participant not withstanding their different levels of formal education to acquire skills, vocational capabilities and managerial/entrepreneurial skills and performances enhancing attributes in their chosen areas of engagement. The programme includes training apprenticeship, investment inducement, seminars, exposition of participants to various applications of science and technology, adoption of simple technologies in the exploration and exploitation of available resources. The concern is to recruit, retain and redeploy the creative capacity of the unemployed so that they can play more productive and self- fulfilling roles in the emerging economic dispensation.

The NAPEP in Gombe state provided under Capacity Acquisition Programme some training and skills of self-reliance from 2004-2006 which aimed at reducing the level of unemployment among our youths, by training them to acquire skills. With the implementation, 5434 participants both male and female for the programme alone involves the selections and posting of the participants to over forty (40) training centers on various trades to enable them acquire skills for self-employment. These trades and skills includes; tailoring/fashion design, blacksmithing, carpentry, hair dressing, knitting, furniture making, welding and iron bending, photography, barbing, vulcanizing, weaving, block molding, printing and graphic arts, radio/TV repairs, laundry services, cloth weaving, leather works, poultry farming, animal fattening, video production, pottery, motor mechanics, hotel management, tea selling, bicycle repairs, butchering/Suya selling, groundnut oil processing, curving/decorations, bee farming, car wash, moi-moi making, arts design, electrical wiring, akamu making, zobo drinks, daddawa processing, fruits/juice making, computer services, dry seasoning farming, soap/pomade making (Yakubu, 2009:4).

Under the Capacity Acquisition Programme (CAP), all the trainees were paid N3, 500.00 each per month over a period of 3 months training, to facilitate means of transports and feeding. The trainers were also paid N3, 500.00 training fees. Under this programme, a selection of 650 unemployed youths that were graduates who have undergone the compulsory one-year National Youth Service. In Gombe state, one hundred (100) centers were utilized including ministries, parastatals, agency NGOs just to mention but a few; participants in this programme were paid N100,000.00 each per month as allowances over a period of one year, while the centers received free services (Yakubu, 2009:4).

To compliment the efforts of the trainees, the National Poverty Eradication Programme allocated one hundred and eleven (111) fashion design machines to Gombe state participants, who graduated in the tailoring trade. The cost prices of these machines were substantially subsidized ranging from N6, 000.00 for straight sewing and zigzag machines and N24, 000.00 for embroidery machines. Most of the graduates of this trade, have long established their own fashion design centers, across the state (Yakubu, 2009:5). 


\section{Macrothink}

The state NAPEP also compliments the effort of NAPEP at the national level. The state NAPEP embarked on various Capacity Acquisition Programme (CAP) activities such as loans to various groups across the state. This is indicated below:

Table 5. Disbursement of loans under Capacity Acquisition Programme in Gombe State

\begin{tabular}{lll}
\hline S/No & Groups & No. of beneficiaries \\
\hline 1. & Artisans (blacksmith, handcraft, tailoring) & 4996 \\
2. & Traders (fruit sellers, butchers e.t.c.) & 562 \\
3. & Medium class traders & Association \\
4. & Small scale/cottage industries & Association \\
5. & Irrigation/water pumps & 500 \\
6. & Staff loans & 12 \\
7. & Motorcycle loans & 394 \\
\hline
\end{tabular}

Source: (NAPEP Gombe State, 2007)

The total amount of money allocated for all the programmes scheduled above was one hundred and thirty-four million seven hundred and fifty-nine thousand and five hundred Naira (N134, 759, 500).

The second aspect of state's NAPEP in Capacity Acquisition Programme (CAP) is workshop on soap and candle processing to participants in the three senatorial districts in march 2003; seminar organized for local government chairmen and secretaries on modalities to cushion the effects of poverty in the localities; workshop on quality improvement for groundnut oil extraction and processing for women across the state and workshop on agro-processing and packaging garlic spices.

There is also evidence of collaboration with donor as presented below. Agency/participant in the programme;

Table 6. Evidence of Collaboration with Donor as Presented below Agency/Participant in the Programme

\begin{tabular}{l|l|l}
\hline S/No & Name of donor agency & Name of programme \\
\hline 1. & LGA & Seminar \\
2. & NAPEP (national) & Assisted with office equipment \\
3. & UNDP & Improved g/nut oil extraction \\
4. & NDE & Vocational training proposals \\
5. & MOC 1 & Agro-processing packaging \\
\hline
\end{tabular}

Source: (NAPEP Gombe state, 2007).

The above donor agencies provided the total sum of eighteen million and two hundred thousand Naira $(\mathrm{N} 18,200,000)$ for the state NAPEP to execute the programmes listed in the table with the provision of the state government for the remaining funds and necessary 
equipment needed.

In addition, the data obtained from the field revealed the perceptions and views of the respondents in the following analysis. some section of the respondents believed that the policy of CAP is beneficial with $99(47.1 \%)$ responding yes from the interviewers, $96(45.7 \%)$ responding no while $15(7.1 \%)$ chose to remain silent on the issue. The ratings of the overall impacts of the programme of CAP under NAPEP disclosed from the respondents that 68 $(32.4 \%)$ gave a very high rating, $65(30.9 \%)$ perceived the programme as average, $65(30.9 \%)$ saw the programme as very low with $15(7.1 \%)$ remains indecisive.

Using the data obtained from the field survey as complemented by various reports, statistics, national surveys, the research discovered the following.

Capacity Acquisition Programme (CAP) as a means of training and empowering people to be self-reliant for poverty eradication failed to actualize its ambition because of problems associated with it many youths were trained but could not be given adequate skill required or empowerment after the training in terms of capital for a start. The beneficiaries turned out to be not any better than before since no bold measures were taken to ensure that they depend on themselves after the programme is finished.

It is also discovered that, despite the increase in revenue generation capacity of Gombe State and increase in federal allocation, there is population explosion which the policy-makers are not paying attention to. Policy of poverty eradication like CAP needs to consider population projection which it failed to do. While CAP target youth and majority male section of the population, the old ones, children and women were neglected and these are the portions mostly affected by poverty.

The procedure for the selection of beneficiaries for CAP programme is faulty. Majority of the respondents agreed that, beneficiaries were chosen mainly on the ground of access to influential people who enlisted them into the programme, particularly for the sake of allowances given monthly, not necessarily for the training session which aimed at making them self-reliant and gainfully employed after the programme.

The implementation process of CAP is not appropriate for sincere poverty alleviation. A trainer interviewed revealed that, the trainees attached to him absconded and failed to acquire the skills they are meant to obtain. The lack of political will is a factor here leading to the poor implementation. At times, CAP looks like one of those policies initiated by the government not sincerely for genuine purpose but, to gain popularity among the masses for the policy later to be abandoned halfway. The policy is not ideal for poverty eradication in Gombe State presently if there is no genuine political will.

The research also discovered that the incidence of poverty keeps on increasing in Gombe State instead of reducing. From the period of the introduction of CAP under NAPEP, a significant rise in figure of those identified to be poor in Gombe State is enough to show that, CAP is not the solution to poverty eradication or rather, implementation process of the CAP. For instance, in 1996, those in poverty level in Gombe State are reported to be $56.4 \%$. In 2001 , during the period of the introduction of CAP, the figure rose to $70.6 \%$. The figure 
however fall to $64.2 \%$ in 2004 and rose to $70.4 \%$ in 2007 , But, the percentage increase to $72.4 \%$ in 2010 and $74.6 \%$ in January 2013 as reported by Ministry of Economic Planning in Gombe State.

\section{Practical Implications}

The research has practical implications for policy-makers, analysts, researchers and public in Gombe State and Nigeria at large. The implication to the policy-makers is the fact identified from the findings that the programme failed in poverty eradication and suggestions were made below in recommendations for an alternative towards eradicating poverty in Nigeria. If the measures are put into practice by the government, a more practical and pragmatic approach will ensure that more than half of those affected by the poverty incidence are lifted out of it within a short period of a time.

The work has practical implication for analysts in the sense that it will provide them with scientific tools and statistics for making of reference and factual analysis of the situation of Nigerian poverty on ground. The work also has practical implication for researchers who are interested in further research on the subject matter of study investigated. The research provides an avenue for scholars to expand in future on the topic studied particularly with reference to Gombe State where no such works exist presently. The research has practical implications on the public specifically those that fall within the category of absolute poverty who can understand their situation clearly, perceive the failure of the programme targetted at them and device other means of complementing the government efforts by utilising available opportunities to them instead of waiting for the policy-makers to provide solution to their predicament.

\section{Conclusion and Recommendation}

\subsection{Conclusion}

It can be deduced from the research conducted here that poverty increase in the whole of Nigeria and Gombe state. This is because the rate of poverty incidence keeps shooting up despite many attempts by Nigerian government to curb it. The National Poverty Eradication Programme was introduced in 2001 to eradicate poverty objectively by the year 2015 . After six years of experimentation, the country emerged as 26 poorest country of the World, as against 36 before 2001. This clearly shows that, the policy failed to impact positively on the targeted population. The poor became poorer because of poor economic policies which tantamount to unemployment, unbearable, inflation rate, high cost of production, insecurity, declining standard of education etc. all these disclosed that, the poverty eradication programme strategy adopted is not ideal for Nigeria.

The study of Capacity Acquisition Programme (CAP) in Gombe state disclosed that, the policy has proved to be failure. In the first place, if one takes the percentage of those living in poverty in the selected areas of study even if CAP succeed in eradicating poverty from the selected beneficiaries, before the programme is concluded, many will be in poverty that are not before the take - off of the programme. 


\subsection{Recommendations}

The research recommends the following if poverty is to be eradicated sincerely and promptly in Gombe State and Nigeria at large:

1. The population section identified to be poor should be given a through supervision to ensure that they attend training regularly for skill acquisition:

2. In any poverty eradication policy in Gombe State, judicious use of revenue accrued to the state is necessary vis-à-vis the population especially the section identified as poor;

3. For a sincere poverty eradication policy to be on ground, the agencies responsible for data collection should be given a free hand to identify the beneficiaries;

4. In order to curb the menace of rising poverty figures in Gombe State, there is need for serious tackling of other issues that are related to poverty or poverty indicators;

5. There is need for the government to borrow from other poverty eradication scheme obtainable in other developing countries particularly, which proved to be vibrant in reducing deprivation and dependency problems and Nigeria at large should borrow Brazilian Bolsa Familia which is Conditional Cash Transfer and

6. The government also needs to improve people's income by embarking on serious macro-economic policies that can affect the whole population. There is need to create many jobs, facilitate industrialization, mechanized agriculture, increase the value of currency, promote export of local products, reduce inflation and local company tax etc to boost and improve economic activities that will improve people's income.

\section{References}

Ajegi, S. O. (2002). The Affluence of Poverty, Department of Economic, Makurdi: Benue State University.

Ake, C. (1996). Democracy and Development in Africa, Washington: Brookings Institution.

Aliyu, S. U. R (2008). Poverty, Causes Nature and Measurement. In Duze, M. C. Mohammed, H. and Kiyawa, I. A. (Eds.) Poverty in Nigeria; Causes, Manifestations and Alleviation Strategies, London: Adonis and Abbey.

Fwatshak, S. U. (2006), Globalisation and Economic Development in Nigeria; the challenges of poverty reduction through E- commerce. In Osaghae, M. \& Pam, G. (Eds.) Globalisation and Cultural Impoverishment of Africa. Spectrum: Ibadan. Gombe State Government (2016). Annual Publication.

Hill, M. S. (1985). The Changing Nature of Poverty. Annals of the American Academy of Political and Social Sciences, 47(9), 31-47. https://doi.org/10.1177/0002716285479001003

Human Development Index 2008. Year Book Retrieved from http://hdr.undp.org/sites/default/files/reports/269/hdr_2009_en_complete.pdf.

Human Poverty Index in Nigeria 2004. Retrieved from 
http://hdr.undp.org/sites/default/files/nigeria_2004_en.pdf.

Ijaiya, G. T. (2007). Poverty Alleviation Programmes in Nigeria Reform Programme; Issues and Challenges. Amali, S. E. Olawepo, R. (Eds.). Ibadan: Vantage publishers limited.

Jhingan, L. M. (2007). The Economic of Development and Planning, Delhi: Vrinda publication.

Keynes, J. M. (1992). The General Theory of Employment, Interest and Money, Washington.

Kpakol, M. (2004). National Poverty Eradication Programme; Capacity Acquisition Programmes (CAP) for 2004 in Gombe; a paper presented in NAPEP, Gombe state.

Magaji, S. (2005). The Mystery of Poverty Eradication in weekly Trust Vol.8 no. 36 Abuja: Media Trust, Limited. Retrieved from www.dailytrust.com.

Mahbub, U. H. (1999). Monitoring Poverty in Asia; Measurement Indicators in Survey Pakistan: Human Development Centre.

Myrdal, G. (1974). Asian Drama vol.1 \&2, An Inquiry into the Poverty of Nations, Sweden: Stockholm. National Bureau of Statistics 2012. Retrieved from http://nigerianstat.gov.ng/.

National Bureau of Statistics 2015. Retrieved from http://nigerianstat.gov.ng/.

National Economic Empowerment Development Strategy (NEEDS) Gombe State 2011.

National Poverty Eradication Programme 2004.

National Poverty Eradication Programme 2010.

National Poverty Eradication Programme Gombe State 2007.

Nurkse, R. (1967). Problems of Capital Formation in Underdeveloped Countries and Patterns of Trade and Development, New York: Oxford University press.

Nwagbara, E. N. (1997). The Globalization phenomenon and the increasing Rate of Poverty in Africa; toward a cautions Response. In Odusola, A. F. (Ed.), "Poverty in Nigeria; An Eclectic Appraisal" in Poverty Alleviation in Nigeria, selected papers for the 1997 Annual Conference, the Nigerian Economic Society (1997), Nigeria: University of Ibadan.

Odusola, A. F. (1997). Poverty in Nigeria; An Eclectic Appraisal. In Poverty Alleviation in Nigeria, selected papers for the 1997 Annual Conference, the Nigerian Economic Society (1997), Nigeria: University of Ibadan.

Offiong, D. A. (1980). Imperialism and Dependency, Onitsha: Fourth Dimension publishers, Nigeria.

Onimode, B. (1983). Imperialism and underdevelopment in Nigeria, Ibadan: Macmillan.

Orji, J. T. (2008). New Approaches to Effective Poverty Alleviation in Nigeria, Kaduna: Joyce Graphic.

Rodney, W. (1979). How Europe Underdeveloped Africa. Panaf: London. 


\section{Macrothink}

Journal of Public Administration and Governance ISSN 2161-7104 2019, Vol. 9, No. 2

Sen, A. (1997). Concept of Human Development and Poverty; A Multidimensional Perspective, India: Delhi.

Smith, A. (1759). An Inquiry into the Wealth of Nations, London: Oxford.

Somasundara, D. (2010). Professor Dayawanda Somasundara Felicitation Ceremony 2010 to appreciate the forty years (40) of service to the Field of Education, Sri Lanka.

United Nations Development Programme 2012. Retrieved from http://dfat.gov.au/about-us/publications/Documents/undp-assessment.pdf.

Yakubu, M. (2009). Lance, on Skill Acquisition to Unemployed Youth Wing of Christian Association of Nigeria (YOWICAN) Gombe State chapter; A paper presentation by State Coordinator (NAPEP), 11 September, 2009.

\section{Copyright Disclaimer}

Copyright for this article is retained by the author(s), with first publication rights granted to the journal.

This is an open-access article distributed under the terms and conditions of the Creative Commons Attribution license (http://creativecommons.org/licenses/by/4.0/). 